\title{
Fotosintezės pigmentų kiekio ir spalvos kitimas mažosiose salotose laikymo metu
}

\author{
Živilè Tarasevičienè, \\ Orinta Aleknavičiūtė, \\ Aloyzas Velička, \\ Judita Černiauskienė, \\ Aurelija Paulauskienè, \\ Vitalija Jurevičienė, \\ Aurimas Krasauskas, \\ Dalè Televičiūtè
}

Aleksandro Stulginskio universitetas, Studentug. 11, LT-53361

Akademija, Kauno r.

El.paštaszivile.taraseviciene@asu.lt
Tyrimai atlikti Aleksandro Stulginskio universitete. Tirtos keturių veislių mažosios salotos: raudonlapès 'Ovired' ir 'Redza' bei žalialapès 'Alanet' ir 'Lettony'. Salotos pasėtos $2015 \mathrm{~m}$. gegužès $8 \mathrm{~d}$., nuimtos $-2015 \mathrm{~m}$. birželio 5 d. Laikytos šaldytuve $2 \pm 0,5^{\circ} \mathrm{C}$ temperatūroje esant $90 \%$ santykiniam drègniui 14 dienų. Laikomose salotose analizuoti fotosintetinių pigmentų kiekio ir spalvos pokyčiai. Spalvos pokyčiai įvertinti spektrofotometru nustačius $L^{\star} a^{\star} b^{\star}$ koordinačių reikšmes NBS vienetais, o fotosintetinių pigmentu - ištyrus chlorofilo $a$ ir $b$ bei bendrą karotenoidų kiekị. Laikymo metu fotosintetinių pigmentų kiekis visų tirtųjų veislių mažujų salotų lapuose keičiasi labai nežymiai. Keturiolika laikymo dienų nepaskatino salotų senejjimo proceso tiek, kad būtu nustatytas statistiškai esminis chlorofilo $a$ skilimas, o chlorofilo $b$ pokyčiai dar mažesni. Bendrasis karotenoidų kiekis statistiškai esminiai didejo visų veislių, išskyrus 'Ovired', salotų lapuose. Spalva priklauso nuo genetinių salotų veislių savybių, tačiau laikymo metu kai kurie spalviniai komponentai skyla, ir maisto žaliavų spalva keičiasi. Laikant mažąsias salotas keičiasi jų $L^{*}$ koordinatès reikšmė, salotų lapai šviesejja, o žalialapių salotų lapų spalvos koordinatės $b^{*}$ reikšmè didëja (salotos gelsta).

Raktažodžiai: bendras karotenoidų kiekis, chlorofilas $a$ ir $b$, laikymas, lapinès salotos, spalva

\section{IVADAS}

Siekiant patenkinti kintančius vartotojų poreikius, kuriami ir tiriami naujų veislių žemès ūkio augalai. Salotos užima didelę visų suvartojamų šviežių daržovių dalị ir yra ekonomiškai svarbus žemès ūkio produktas (Moreira et al., 2014). Tai populiariausios lapinès daržovès, dažniausiai naudojamos termiškai neapdorotos (Mulabagal et al., 2010). Išskiriamos penkios pagrindinès sejjamosios salotos (Lactuca sativa L.) rūšys: gūžinès, aisbergo tipo, lapinès, romaninès ir smidrinès (Zlotek et al., 2014). Pastaruoju metu populiarejja mažosios salotos, kurios prieš pateikiant vartotojams tik nuplaunamos ir pakuojamos nesmulkintos. Jų struktūra išlieka patraukli, o dèl mažo stiebo pjūvio ploto išvengiama intensyvaus oksidacijos proceso. Toks produktas yra stabilesnis, geriau išsilaiko (Martínez-Sáncheza et al., 2012). Mažosios salotos ir kitos mažosios maisto žaliavos - tai jaunos žalumyninès daržovès, dažniausiai įvairių veislių salotos, špinatai, burokèlių lapai, gražgarstès ir kt. Jos maistui vartojamos dar nepasiekusios brandos, suformavusios 4-6 tikruosius lapelius.

Šių daržovių vartojimas skatinamas ne vien tik dèl mineralinių medžiagų ar vitaminų kiekio jose, tačiau taip pat dèl kitų mažais kiekiais aptinkamų biologiškai aktyvių komponentų, kurie pasižymi teigiamu poveikiu žmogaus organizmui (Kim et al., 2008). Dalis šiomis savybėmis pasižyminčių junginių suteikia produktui spalvą ir skonị.

Pagrindiniai vartotojų pasirinkimo kriterijai yra vartojimo patogumas, šviežumas, aromatas, spalva ir kokybė. Vienas pirmụjų, dèmesị patraukiančių ar atstumiančių rodiklių, yra spalva. Augalinių produktų spalvą lemia pigmentinès medžiagos, esančios produktuose. Tai pirminiai ir antriniai augalu metabolitai, pasižymintys skirtingu stabilumu ir kitomis savybėmis. Vienas svarbiausių šviežių lapinių daržovių kokybinių rodiklių - žalios spalvos 
pasikeitimas - priklauso nuo chlorofilo skilimo intensyvumo (Aguero et al., 2008). Chlorofilo skilimo intensyvumą lemia apšvietimas, temperatūra, drègnis, deguonis, etilenas bei chlorofilazès ir kitų fermentų aktyvumas (Yamuchi, Watada 1991, Jacob-Wilk et al., 1999). Žalios spalvos praradimas susijęs su chlorofilo $b$ formos virtimu $a$ forma (Ohtsuka et al., 1997).

Darbo tikslas - įvertinti skirtingu veisliu mažųjų salotų fotosintetinių pigmentų ir spalvos pokyčius laikymo metu.

\section{TYRIMŲ METODAI IR SĄLYGOS}

Tyrimai atlikti Aleksandro Stulginskio universitete. Tirtos šių veislių mažosios salotos: raudonlapès 'Ovired' ir 'Redza' bei žalialapès 'Alanet' ir 'Lettony'. Salotos augintos ASU pomologiniame sode. Pasètos $2015 \mathrm{~m}$. gegužès $8 \mathrm{~d}$., nuimtos - $2015 \mathrm{~m}$. birželio $5 \mathrm{~d}$. Nuemus salotas jos nuplautos ir per 4 valandas nuo derliaus nuèmimo sudètos ì užspaudžiamus perforuotus $150 \times 220 \mathrm{~mm}$ dydžio, 35-45 mikronų storio maišelius. Laikytos $2 \pm 0,5{ }^{\circ} \mathrm{C}$ temperatūroje esant $90 \%$ santykiniam drègniui dvi savaites.

Spalva nustatyta spekrofotometru ColorFlex EZ (Hunter Associates Laboratory Inc., JAV). Ivertintas šviesumas $L^{*}\left(0\right.$ - juoda, 100 - balta), $a^{*}$ koordinatès vertė (raudona / žalia, raudonos spalvos intensyvumas, kai $a^{\star}>0$, žalios, kai $a^{*}<0$ ), $b^{*}$ koordinatè (geltona / mèlyna, geltonos spalvos intensyvumas, kai $b^{\star}>0$, mèlynos, kai $b^{\star}<0$ ) pagal CIELab skalę, išreiškiant NBS vienetais. NBS vienetas - tai JAV Nacionalinio standartų biuro vienetas, atitinkantis vieną spalvų skiriamosios galios slenksti, t. y. mažiausias spalvos skirtumas, kurị gali užfiksuoti treniruota žmogaus akis (AOAC, 1990). Tyrimai atlikti CIEL ${ }^{\star} a^{\star} b^{\star}$ vienodo kontrasto spalvų erdveje (CIE $\left.L^{*} a^{*} b^{*}, 1996\right)$. Prieš kiekvieną matavimų seriją spektrofotometras kalibruotas baltos ir juodos spalvos plokštelèmis.

Chlorofilo $a$ ir $b$ bei karotenoiduc kiekiai nustatyti dviejų spindulių UV-Vis spektrofotometru UVS-2800 (Labomed Inc., USA). Absorbcija ịvertinta esant 470, 645 ir $662 \mathrm{~nm}$ bangos ilgiui, naudojant stiklines kiuvetes. Chlorofilų ir karotenoidų kiekis paskaičiuotas pagal A. R. Wellburn (1994). Pigmentams nustatyti 0,4 g salotų lapų buvo homogenizuoti, ekstrahuoti acetonu, kolbas $15 \mathrm{~min}$. purtant magnetine purtykle, kai apsisukimų skai- čius 700 per min. Ekstrakcija pakartota du kartus (Straumite et al., 2015).

Laikymo bandymas atliktas trimis pakartojimais, cheminès analizès darytos dviem pakartojimais. Duomenų matematiniam ir statistiniam įvertinimui atlikta dviejų veiksnių dispersinè analizè (ANOVA). Vienas veiksnys - mažųjų salotų veislè, kitas - salotų laikymo trukmè. Skirtumų tarp vidurkių statistinis patikimumas įvertintas $\mathrm{Fi}$ šerio LSD testu $(p<0,05)$. Duomenys statistiškai apdoroti kompiuterine programa STATISTICA 7.

\section{TYRIMU REZULTATAI IR JŲ APTARIMAS}

Spalva - vienas svarbiausių augalinių žaliavų kokybės rodiklių. Nuo spalvos intensyvumo ir priimtinumo priklauso ir vartotojų pasirinkimas. Laikant augalines maisto žaliavas, jų spalva keičiasi priklausomai nuo laikymo trukmès ir sąlygų. Nors ir nežymiai, tačiau statistiškai esminiai kito laikomų salotų šviesumas. Tik veislès 'Ovired' salotų lapų šviesumas (koordinatė $L^{\star}$ ) visą laikymo laikotarpi iš esmès nepasikeitè (1 lentelè). Žalialapių 'Alanet' ir 'Lettony' veisliu salotos po 14 laikymo dienu pašviesejo ( $L^{\star}$ kito atitinkamai 5,79 ir 3,05 NBS vieneto). Spalvos koordinatès $a^{*}$ teigiamas skaičius rodo raudoną spalvą, o neigiamas - žalią. Raudoniausi buvo 'Redza' veislès salotų lapai, o žaliausi - 'Alanet' ir 'Lettoni' veislių. Visų tirtųjų veislių salotų lapų spalvos koordinatès $a^{\star}$ reikšmé statistiškai esminiai laikymo metu nesikeičia, todèl galima daryti prielaidą, kad pigmentų, lemiančių rausvą ir žalią spalvą kiekis salotų lapuose išlieka stabilus. Mažiausia $b^{*}$ koordinatès reikšmè nustatyta 'Redza' (raudonlapių) salotų lapų, o intensyviausiu gelsvu atspalviu pasižymėjo žalialapių 'Alanet' ir 'Lettony' veislių salotų lapai. Tik 'Alanet' salotų lapu $b^{*}$ koordinatès reikšmè laikymo metu kito iš esmès. Po 10 laikymo dienų 'Alanet' salotų lapų $b^{*}$ koordinatès reikšmè padidèjo 3,25 NBS vieneto (salotų lapai iggavo intensyvesnị gelsvą atspalvị).

Laikymo proceso metu chlorofilo kiekis mažeja beveik visų rūšiu daržovèse. Dažniausiai chlorofilo kiekio sumažejimas siejamas su daržovių pageltimu, tačiau chlorofilas gali skilti ir dèl pjaustytu daržovių, užpiltų salotų pagardais, patamsèjimo. Abu produkto spalvos netekimo atvejai siejami su tuo pačiu chlorofilo skilimo keliu, tačiau patamsèjimas yra nepilno chlorofilo molekulès metabolizmo 
1 lentelè. Laikomų skirtingų veislių mažųjų salotų lapų spalvos pokyčiai NBS vienetais

Table 1. The colour changes in different varieties of baby lettuces during storage, NBS units

\begin{tabular}{c|c|c|c|c}
\hline $\begin{array}{c}\text { Veislé } \\
\text { Variety }\end{array}$ & $\begin{array}{c}\text { Laikymo trukme dienomis } \\
\text { Storage time in days }\end{array}$ & $\begin{array}{c}\text { Koordinate } \boldsymbol{L}^{*} \\
\text { Coordinate } \boldsymbol{L}^{*}\end{array}$ & $\begin{array}{c}\text { Koordinate } \boldsymbol{a}^{*} \\
\text { Coordinate } \boldsymbol{a}^{*}\end{array}$ & $\begin{array}{c}\text { Koordinate } \boldsymbol{b}^{*} \\
\text { Coordinate } \boldsymbol{b}^{*}\end{array}$ \\
\hline 'Redza' & 0 & $23,25 \mathrm{a}$ & $4,25 \mathrm{~d}$ & $1,05 \mathrm{a}$ \\
\hline & 6 & $25,33 \mathrm{ab}$ & $4,32 \mathrm{~d}$ & $1,34 \mathrm{a}$ \\
\hline & 10 & $24,54 \mathrm{ab}$ & $4,00 \mathrm{~d}$ & $1,61 \mathrm{a}$ \\
\hline 'Ovired' & 14 & $26,29 \mathrm{~b}$ & $4,28 \mathrm{~d}$ & $1,61 \mathrm{a}$ \\
\hline & 0 & $31,65 \mathrm{c}$ & $1,27 \mathrm{c}$ & $10,10 \mathrm{~b}$ \\
\hline & 6 & $32,81 \mathrm{c}$ & $1,85 \mathrm{c}$ & $9,16 \mathrm{~b}$ \\
\hline & 10 & $32,10 \mathrm{c}$ & $1,43 \mathrm{c}$ & $9,94 \mathrm{~b}$ \\
\hline 'Alanet' & 14 & $34,05 \mathrm{c}$ & $1,21 \mathrm{c}$ & $10,91 \mathrm{~b}$ \\
\hline & 0 & $40,36 \mathrm{~d}$ & $-8,87 \mathrm{a}$ & $25,65 \mathrm{c}$ \\
\hline & 6 & $42,45 \mathrm{def}$ & $-6,59 \mathrm{~b}$ & $25,88 \mathrm{~cd}$ \\
\hline & 10 & $45,59 \mathrm{~g}$ & $-9,40 \mathrm{a}$ & $27,98 \mathrm{ef}$ \\
\hline 'Lettony' & 14 & $46,15 \mathrm{~g}$ & $-9,46 \mathrm{a}$ & $28,90 \mathrm{f}$ \\
\hline & 0 & $40,90 \mathrm{de}$ & $-9,65 \mathrm{a}$ & $26,26 \mathrm{cde}$ \\
\hline & 6 & $41,23 \mathrm{def}$ & $-9,28 \mathrm{a}$ & $25,90 \mathrm{~cd}$ \\
\hline & 10 & $43,58 \mathrm{efg}$ & $-9,49 \mathrm{a}$ & $27,52 \mathrm{def}$ \\
\hline
\end{tabular}

Pastaba / Note: reikšmès, pažymètos tomis pačiomis raidèmis, pagal Fišerio LSD testą $(p<0,05)$ iš esmès nesiskiria / Means followed by the same letter do not differ significantly $(p<0.05)$ according to the Fisher LSD test.

pasekmè (Heaton et al., 1996; Matile et al., 1999). Chlorofilo skilimo intensyvumas, laikant augalines maisto žaliavas, priklauso nuo rūšies, laikymui prailginti naudojamų priemonių ir temperatūrinio režimo laikymo metu (Ibrahim et al., 2004).

Chlorofilo a kiekis mažosiose salotose kito priklausomai nuo veislès ir laikymo trukmès. Esminis chlorofilo $a$ kiekio sumažejjimas nustatytas 'Ovired' lapinèse salotose po 10 laikymo dienų (2 lentelè).

Kitų veislių salotų lapuose šio fotosintezès pigmento kiekis keitèsi labai nežymiai. Keturiolika laikymo dienų nepaskatino salotų senéjimo proceso tiek, kad būtų nustatytas esminis chlorofilo $a$ skilimas. Didžiausias chlorofilo $a$, kaip ir $b$, kiekis nustatytas 'Redza' veislès salotų lapuose, kuriuose šio pigmento kiekis laikymo metu nežymiai, nors statistiškai esminiai, padidejo.

Nustatyta, kad chlorofilo $b$ kiekio kitimą dar mažiau nei chlorofilo $a$ lèmé salotų laikymo trukmé. Tai galima paaiškinti tuo, kad chlorofilas $a$ yra mažiau stabilus nei chlorofilas $b$. 'Ovired' veislès salotų lapuose chlorofilo $b$ kiekis iš esmès sumažèjo po 10 laikymo dienų.
Bendrasis chlorofilo kiekis taip pat kito nežymiai, kadangi atskirų komponentų kitimas nebuvo statistiškai esminis. Bendrasis chlorofilo kiekis iš esmès padidèjo 'Redza' veislès salotų lapuose. Intensyviausias bendrojo chlorofilo kiekio sumažejimas laikymo metu nustatytas 'Ovired' salotu lapuose. Pokytis lyginant bendrajji chlorofilo kieki prieš laikymą ir po sudare $0,07 \mathrm{mg} \mathrm{g}^{-1}$.

Skirtingų formų chlorofilo santykiui esminès itakos turèjo salotu genetinès savybès, tačiau ne laikymo trukmè. Optimaliausias augalui chlorofilo santykis nustatytas 'Redza' veislès salotų lapuose ir kito nuo 3,49 iki 3,72 $\mathrm{mg} \mathrm{g}^{-1}$ laikymo metu.

Dažniausiai chlorofilo kiekis daržovèse pradeda mažèti po 5 laikymo dienų, tačiau gali būti ir kitokių svyravimų. Laikant 4 ar $10{ }^{\circ} \mathrm{C}$ temperatūroje tamsoje salotines sultenes chlorofilo ir karotenoidų kiekio mažejimas nustatytas tik po 8 laikymo dienų (Ferrante, Maggiore, 2007). A. Spinardi ir A. Ferrante (2012) nustaté, kad, laikant mažąsias salotas 14 dienų 4 ir $10^{\circ} \mathrm{C}$ temperatūroje nei chlorofilo, nei karotenoidų kiekis iš esmès nesikeitè. 
2 lentelè. Fotosintezès pigmentų žaliosios medžiagos pokytis laikomose skirtingų veislių mažosiose salotose $\left(\mathrm{mg} \mathrm{g}^{-1}\right)$ žalioje medžiagoje

Table 2. The change of photosynthetic pigment amounts in different varieties of baby leaves lettuce during storage ( $m g g^{-1}$ fresh matter)

\begin{tabular}{c|c|c|c|c|c|c}
\hline $\begin{array}{c}\text { Veislè } \\
\text { Variety }\end{array}$ & $\begin{array}{c}\text { Laikymo trukmé } \\
\text { dienomis } \\
\text { Storage time in days }\end{array}$ & $\mathbf{C h l ~ a}$ & $\mathbf{C h l ~ b}$ & $\mathbf{C h l ~} \mathbf{a} \mathbf{~ b}$ & $\mathbf{C h l} \mathbf{a} / \mathbf{b}$ & $\begin{array}{c}\text { Bendrasis karotenoidu } \\
\text { kiekis }\end{array}$ \\
\hline 'Redza' & 0 & $0,42 \mathrm{~g}$ & $0,12 \mathrm{~h}$ & $0,55 \mathrm{~g}$ & $3,49 \mathrm{a}$ & $0,19 \mathrm{fg}$ \\
\hline & 6 & $0,46 \mathrm{~h}$ & $0,14 \mathrm{j}$ & $0,59 \mathrm{~h}$ & $3,45 \mathrm{a}$ & $0,21 \mathrm{~h}$ \\
\hline & 10 & $0,47 \mathrm{hj}$ & $0,13 \mathrm{~h}$ & $0,60 \mathrm{~h}$ & $3,70 \mathrm{a}$ & $0,22 \mathrm{~h}$ \\
\hline 'Ovired' & 14 & $0,46 \mathrm{~h}$ & $0,12 \mathrm{~h}$ & $0,58 \mathrm{~h}$ & $3,72 \mathrm{a}$ & $0,22 \mathrm{~h}$ \\
\hline & 0 & $0,34 \mathrm{bc}$ & $0,07 \mathrm{de}$ & $0,41 \mathrm{bc}$ & $4,57 \mathrm{bc}$ & $0,15 \mathrm{cde}$ \\
\hline & 10 & $0,32 \mathrm{~b}$ & $0,07 \mathrm{~cd}$ & $0,39 \mathrm{~b}$ & $4,73 \mathrm{c}$ & $0,15 \mathrm{~cd}$ \\
\hline 'Alanet' & 14 & $0,27 \mathrm{a}$ & $0,06 \mathrm{~b}$ & $0,33 \mathrm{a}$ & $4,63 \mathrm{bc}$ & $0,13 \mathrm{a}$ \\
\hline & 0 & $0,28 \mathrm{a}$ & $0,06 \mathrm{bc}$ & $0,34 \mathrm{a}$ & $4,39 \mathrm{bc}$ & $0,14 \mathrm{ab}$ \\
\hline 6 & $0,32 \mathrm{~b}$ & $0,07 \mathrm{~d}$ & $0,40 \mathrm{~b}$ & $4,49 \mathrm{bc}$ & $0,15 \mathrm{bc}$ \\
\hline & 10 & $0,35 \mathrm{~cd}$ & $0,07 \mathrm{~d}$ & $0,41 \mathrm{bc}$ & $4,69 \mathrm{c}$ & $0,17 \mathrm{e}$ \\
\hline 'Lettony' & 14 & $0,34 \mathrm{bc}$ & $0,08 \mathrm{de}$ & $0,42 \mathrm{bc}$ & $4,53 \mathrm{bc}$ & $0,15 \mathrm{bc}$ \\
\hline & 0 & $0,35 \mathrm{~cd}$ & $0,08 \mathrm{ef}$ & $0,43 \mathrm{~cd}$ & $4,30 \mathrm{~b}$ & $0,16 \mathrm{cde}$ \\
\hline & 10 & $0,41 \mathrm{fg}$ & $0,09 \mathrm{~g}$ & $0,51 \mathrm{f}$ & $4,37 \mathrm{bc}$ & $0,20 \mathrm{~g}$ \\
\hline & 14 & $0,37 \mathrm{de}$ & $0,09 \mathrm{f}$ & $0,46 \mathrm{de}$ & $4,36 \mathrm{bc}$ & $0,18 \mathrm{f}$ \\
\hline
\end{tabular}

Pastaba / Note: reikšmès, pažymètos tomis pačiomis raidèmis, pagal Fišerio LSD testą $(p<0,05)$ iš esmès nesiskiria / Means followed by the same letter do not differ significantly $(p<0.05)$ according to the Fisher LSD test.

Bendrasis karotenoidų kiekis augalo ląstelèse susijęs su chlorofilo sinteze. Nors karotenoidu kiekis visų tirtųjų veislių salotų lapuose buvo labai panašus, tačiau didžiausias šių tetraterpenų kiekis nustatytas 'Redza' veislès salotų lapuose, kurie pasižymi rausva spalva, o mažiausias - 'Ovired' salotų lapuose. Bendrasis karotenoidų kiekis tirtụjų veislių salotų lapuose statistiškai esminiai didejjo, išskyrus 'Ovired' salotų lapus (2 lentelè). Laikymo metu karotenoidų kiekis, nepriklausomai nuo salotų veislès, padidèjo $0,01-0,03 \mathrm{mg} \mathrm{g}^{-1}$. Karotenoidų kiekio padidèjimas gali būti susijęs su drègmès netekimu laikomose salotose.

\section{IŠVADOS}

1. Laikant mažąsias salotas $2{ }^{\circ} \mathrm{C}$ temperatūroje iki 14 dienų nustatyta, kad fotosintetinių pigmentų kiekis keičiasi labai nežymiai. Šių metabolitų pokyčiai turètų būti siejami ne tik su laikymo sąlygomis, tačiau taip pat ir su mažųjų salotų veislių genetinèmis savybèmis.
2. Spalva priklauso nuo genetinių salotų savybių, tačiau laikymo metu kai kurie spalviniai komponentai skyla, ir maisto žaliavų spalva keičiasi. Laikant mažąsias salotas keičiasi jų $L^{*}$ koordinatès reikšmė, žalialapių salotų lapai šviesejja ir igauna intensyvesni gelsvą atspalvị.

3. Laikant iki 14 dienų geriausią prekinę išvaizdą išlaikè raudonlapių veislių 'Redza' ir 'Ovired' mažosios salotos.

Gauta 20160406 Priimta 20160609

\section{LITERATŪRA}

1. AOAC. 1990. Official Methods of Analysis. K. Herlich (ed.). Arlington, Virginia: Association of Official Analytical Chemists.

2. Aguero M. V., Barg M. V., Yommi A., Camelo A., Roura S. 2008. I. Postharvest changes in water status and chlorophyll content of lettuce (Lactuca Sativa L.) and their relationship with overall visual quality. Journal of Food Science. Vol. 73. No. 1. P. $1750-3841$. 
3. CIE L*a* $\mathrm{b}^{*}$ Color Scale. 1996. HunterLab Applications Note. Vol. 8(7). P. 1-4.

4. Clarkson G. J. J., O’byrne E. E., Rothwell S. D., Taylor G. 2003. Identifying traits to improve postharvest processability in baby leaf salad. Postharvest Biology and Technology. Vol. 30. No. 3. P. 287-298.

5. Ferrante A., Maggiore T. 2007. Chlorophyll $a$ fluorescence measurements to evaluate storage time and temperature of Valeriana leafy vegetables. Postharvest Biology and Technology. Vol. 45. P. 73-80.

6. Heaton J. W., Yada R. Y., Marangoni A. G. 1996. Discoloration of coleslaw is caused by chlorophyll degradation. Journal of Agricultural and Food Chemistry. Vol. 22. P. 395-398.

7. Ibrahim R., Osman A., Saari N., Rahman R. A. 2004. Effects of anti-browning treatments on the storage quality of minimally processed shredded cabbage. Journal of Food Agriculture and Environment. Vol. 2. No. 2. P. 54-58.

8. Yamuchi N., Watada A. E. 1991. Regulated chlorophyll degradation in spinach leaves during storage. Journal of the Phytol and American Society for Horticultural Science. Vol. 116. P. 58-62.

9. Jacob-Wilk D., Holland D., Goldschmidt E. E., Riov J., Eyal Y. 1999. Chlorophyll breakdown by chlorophyllase: isolation and functional expression of the Chlase 1 gene from ethylene-treated citrus fruit and its regulation during development. The Plant Journal. Vol. 20. P. 653-661.

10. Kim H. J., Fonesca J. M., Choi J. H., Kubota C., Kwon D. Y. 2008. Salt in irrigation water affects the nutritional and visual properties of romaine lettuce (Lactuca sativa L.). Journal of Agriculture and Food Chemistry. Vol. 56. P. 3772-3776.

11. Kishimoto S., Maoka T., Sumitomo K., Ohmiya A. 2005. Analysis of carotenoid composition in petals of calendula (Calendula officinalis L.). Bioscience, Biotechnology and Biochemistry. Vol. 69. P. 21222128.

12. Martinez-Sanchez A., Luna M. C., Selma M. V., Tudela J. A., Abad J., Gil M. I. 2012. Baby-leaf and multi-leaf of green and red lettuces are suitable raw materials for the fresh-cut industry. Postharvest Biology and Technology. Vol. 63. P. 1-10.

13. Matile P., Hortensteiner S., Thomas H. 1999. Chlorophyll degradation. Annual Review of Plant Physiology and Plant Molecular Biology. Vol. 50. P. 67-95.

14. Moreira M. A., Pereira dos Santos C. A., Lucas A. A. T., Bianchini F. B., Machado de Souza I., Viegas P. R. A. 2014. Lettuce production according to different sources of organic matter and soil cover. Agricultural Sciences. Vol. 5. No. 2. P. 99-105.

15. Mulabagal V., Ngouajio M., Nair A., Zhang Y., Gottumukkala A. L., Nair G. N. 2010. In vitro eval- uation of red and green lettuce (Lactuca sativa) for functional food properties. Food Chemistry. Vol. 118. P. 300-306.

16. Ohtsuka T., Ito H., Tanaka A. 1997. Conversion of chlorophyll $b$ to chlorophyll $a$ and the assembly of chlorophyll with apoproteins by isolated chloroplast. Plant Physiology. Vol. 113. P. 137-47.

17. Spinardi A., Ferrante A. 2012. Effect of storage temperature on quality changes of minimally processed baby lettuce. Journal of Food Agriculture and Environment. Vol. 10(1). P. 38-42.

18. Straumite E., Kruma Z., Galoburda R. 2015. Pigments in mint leaves and stems. Agronomy Research. Vol. 13. No. 4. P. 1104-1111.

19. Tanaka Y., Sasaki N., Ohmiya A. 2008. Biosynthesis of plant pigments: anthocyanins, betalains and carotenoids. The Plant Journal. Vol. 54. P. 733-749.

20. WagstaffC., Clarkson G. J.J., Rothwell S. D., Page A., Taylor G., Dixon M. S. 2007. Characterisation of cell death in bagged baby salad leaves. Postharvest Biology and Technology. Vol. 46. No. 2. P. 150-159.

21. Welburn A. R. 1994. The spectral determination of chlorophylls $a$ and $b$, as well as total carotenoids, using various solvents with spectrophotometers of different resolution. Journal of Plant Physiology. Vol. 144(3). P. 307-313.

\section{Živilè Tarasevičienè, Orinta Aleknavičiūtè, Aloyzas Velička, Judita Černiauskienè, Aurelija Paulauskienė, Vitalija Jurevičienė, Aurimas Krasauskas, Dalè Televičiūtė \\ CHANGES OF PHOTOSYNTHETIC PIGMENTS AMOUNT AND COLOUR OF BABY LEAVES LETTUCE DURING STORAGE}

\section{Summary}

Research was carried out at Aleksandras Stulginskis University. Four varieties of baby leaves lettuce were investigated: 'Ovired', 'Redza', 'Alanet', and 'Lettony'. Lettuce was stored for 14 days in a refrigerator at $2 \pm 0.5^{\circ} \mathrm{C}$ temperature and $90 \%$ relative humidity. Chlorophyls, total carotenoid contents, and lettuce colour were determined periodically during the storage. Amounts of photosynthetic pigments in baby leaves during the 14-day storing period in the refrigrator changed slightly. These metabolites changes can be more related with genetic properties of baby leaves than with storing conditions. Colour depends on lettuce genetic properties, but during storage destruction of colourful compounds can be observed and colour of raw agricultural products changes. The value of $L^{*}$ coordinate changes, lettuce leaves lighten, and the value of $b^{*}$ coordinate shows the yellowing of lettuce leaves.

Keywords: chlorophyls $a$ and $b$, colour, leaves lettuce, storage, total amount of carotenoids 